\title{
34-Franz Kafka’nın Dava adlı eseri bağlamında siber gözetim ve birey
}

\section{Onur YILMAZ ${ }^{1}$} APA: Yılmaz, O. (2020). Franz Kafka'nın Dava adlı eseri bağlamında siber gözetim ve birey.
RumeliDE Dil ve Edebiyat Araştırmaları Dergisi, (Ö8), 423-431. DOI: 10.2900o/rumelide.821898.

$\ddot{\mathbf{O} z}$

Mekân ve zaman birlikteliğinin bir zorunluluk olmaktan çımasıyla gözetim de yeni bir biçim kazanmış, kâğıda dayalı gözetim kavramı siber uzayda yeniden anlamlanmıştır. Gözetim altında tutulan bireyin erk tarafından kontrol edilmesi ve yönlendirilmesi günümüzün en sık tartışılan konularından birisidir. Günümüzde birey, siber uzayda sürekli izlendiği, kontrol altına alındığı, izlendiğini bilerek oto sansürü gönüllü bir şekilde oluşturduğu bir yaşam sürmektedir. Kafka bu denetim mekanizmasını daha 20. yüzyılın başlarında görmüş, ve eserlerine yansıtmıştır. Kafka yüzyıl öncesinden eserinde, görünmeyen erk karşısında her şeyi kabul eden, suçlanan, bunu doğal karşlayan ve hatta gündelik hayatına olduğu gibi devam eden bir bireyi tasvir ederek günümüze aktarmıştır. Eserindeki, insanları izleyen sembolik gözler artık ete kemiğe bürünmüs, ve caddelerde, alışveriş, merkezlerinde, okullarda, evlerin girişlerinde bizi izleyen kameralara dönüşmüștür. Çalışmanın amacı edebi eserlere yansıyan siber gözetim, siber uzay gibi kavramların ve sembollerin Dava eseri üzerinden incelenerek çözümlemesinin yapılmasıdır. Bireyin değişen toplumsal olaylar karşısında kendisini koruma ve var etme çabası ele alınmıştır. Sonuç, olarak salgın, terör ve siber saldırılar gibi insanların çaresiz kaldığı ve korku faktörünün en üst seviyede olduğu bir donemde, kişiler bilgiye siber uzay içinde var olan sanal platformlardan ulaşabilmekte ve dolaylı olarak bu gözetleme mekanizmasına da rıza göstermektedirler. Kafka'nın anlatımı üzerinden günümüz insanının içinde bulunduğu durum eser incelemesi yapılarak irdelenmiş, ve insanların sürekli gözetim altında tutulmak konusunda, teknolojinin getirdiği yeni olanaklardan faydalanmak adına tepkisiz kaldığı ortaya konulmuştur.

Anahtar kelimeler: Kafka, siber gözetim, Dava

\section{Cyber surveillance and individual in the context of Franz Kafka's The Trial}

\begin{abstract}
With the fact that togetherness of space and time is no longer a necessity, surveillance has also gained a new form, and the concept of paper-based surveillance has been re-enacted in cyberspace. Controlling and directing the individual under surveillance by the government is one of the most discussed issues of our time. Today, the individual is constantly monitored, controlled and monitored in cyberspace, and the auto censorship voluntarily creates a life. Kafka saw this control mechanism in the early 2oth century and reflected it on his works. Kafka has passed it on to the present day centuries ago in his work, depicting an individual who accepts everything in the face of unseen men, who is accused, who welcomes it naturally and even continues his daily life as it is. The symbolic eyes in his work, which followed people, turned now into cameras that follow us in the streets, shopping malls, schools, entrances of houses. The aim of the study is to examine and
\end{abstract}

Dr., Hacettepe Üniversitesi, Edebiyat Fakültesi, Alman Dili ve Edebiyatı Bölümü (Ankara, Türkiye), onur.yilmaz@hacettepe.edu.tr, ORCID ID: oooo-0002-1006-4441 [Makale kayıt tarihi: 13.09.2020-kabul tarihi: 20.11.2020; DOI: 10.29000/rumelide.821898]

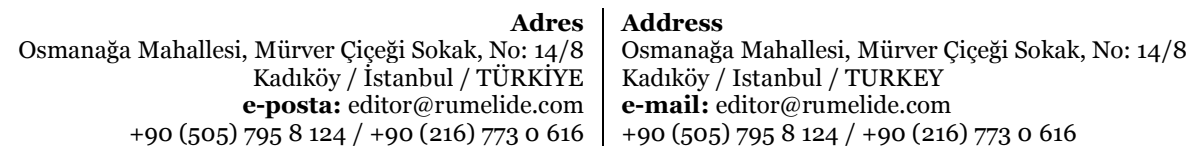


analyze concepts such as cyber surveillance and cyberspace, reflected in literary works through The Trial. The individual's efforts to protect and exist in the face of changing social events have been discussed. As a result, at a time when people such as epidemics, terrorism and cyber attacks are helpless and the fear factor is at the highest level, people can access information from virtual platforms that exist within cyberspace, and indirectly consent to this surveillance mechanism. Kafka's narration was examined by the work review of today's people and it was revealed that people remain unresponsive in order to take advantage of the new possibilities brought by technology in order to keep them under constant supervision.

Keywords: Kafka, cyber surveillance, The Trial

\section{Giriş}

1990'lı yllarla birlikte bilgi ve iletişim teknolojilerinde yaşanan değişimler önce bireyleri daha sonra ise devletleri etkilemiştir. Sosyal bir varlık olan birey, sosyalleşmesini fiziki alandan siber uzaya taşımış ve böylece yeni bir anonim iletişim biçimi ortaya çıkmıştır. Başlarda daha çok eğlence, iletişim biçimi veya sosyal medya olarak bireye daha çok hitap eden siber uzay, daha sonra devletlerin de bu alana dijital olarak girmesiyle hayatımızın vazgeçilemez bir parçası olmuştur. Özellikle kişisel bilgisayar kullanımının artması ve internetin iletişim alanı olarak ortaya çıkması, bilgi iletişim teknolojilerinin yönetişim yapısına dahil edilmesine neden olmuştur. Böylece devletler siber uzaydaki ucuz maliyeti, anında bilgiye erişimi ve bürokrasinin azalması gibi avantajları görerek bu alana e-devlet gibi çeşitli platformlar üzerinden giriş yapmışlardır. Bu yeni açılan alanda devletler kitlelerle bütünleşirken bir yandan da onları yönetmek ve kontrol altında tutmak için yeni yöntemler geliştirmişlerdir.

Günümüzün ve muhtemelen 21. yüzyılın en önemli olaylarından biri olarak tarihe geçecek olan salgın, ekonomik, sosyolojik ve psikolojik olarak dünya genelini etkilemektedir. İnsanlar sosyolojik bir varlık olmasına rağmen bireyselleşme ile beraber daha çok grupların içinde değil de kapalı kapılar ardında tek olarak var olmaya çalışmaktadırlar. Salgın gibi büyük çaplı durumlar kişilerin daha çok eve kapanmasına ve iç dünyası ile baş başa kalmasına neden olmaktadır. Toplumsal düzeni sağlamak isteyen erk için kendi içine kapanmış bireyler daha rahat gözetlenebilir ve kontrol edilebilir konuma doğru yaklaşmışlardır. Gözetim hayatın her alanında varlığını görünür ya da görünür olmayan bir biçimde sürdürmektedir. Gözetleme ve bu sayede denetleme işlevi gelişen dünyada her geçen gün daha çok önem kazanmaktadır.

Gözetim, rekabet mantığına dayanır. İnsanlarla ilgili verileri toplayarak, depolayarak, işleyerek, yayarak, değerlendirerek ve kullanarak grupların veya bireylerin belirli davranışlarını meydana getirmeye veya engellemeye çalışır, böylece potansiyel veya fiili fiziksel, ideolojik veya yapısal şiddetin, davranışlarını etkilemek için insanlara yöneltilebilir (Fuchs, 2017: 158). İnsanlık tarihi kadar eski olan gözetimin yaygınlaşması ve kurumsallaşması yazının kullanılması ve sonrasında matbaanın bulunması ile olmuştur. Başlarda gözetim askeri faaliyetler ve vergi düzenleme gibi kısıtlı alanlarda söz konusu iken günümüzde hayatımızın her alanında karşımıza çıkmaya başlamıştır. Bu çalışmanın amacı, bu yeni durum karşısında kendini daha görünür kılan gözetleme kavramının Franz Kafka'nın Dava adlı romanı üzerinden irdelenmesi ve bireyin varoluşunun ve kendisine yabancılaşmasının sorgulanmasıdır. Çünkü Kafka, yabancılaşma konusunda sistemli bir çalışması olmamasına rağmen eserlerindeki 'konu' ve 'karakterler' ile modern insanın yabancılaşma biçimlerini çarpıcı bir bicimde ortaya koyar (Çiçek, 2015: 144). Dava eserinde bireyin yabancılaşması ve gözetim altında olması siber uzay bağlamında modern gözetim olan siber gözetimin anlaşılmasında katkı sağlayacaktır. Bu

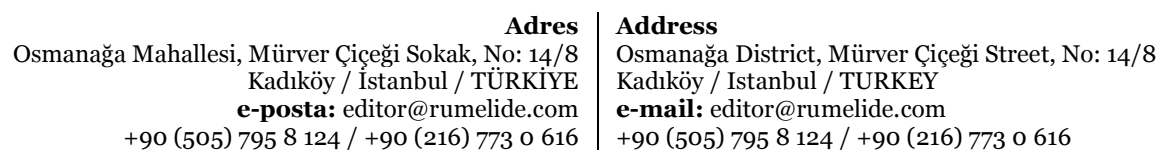


bağlamda, çalışmada önce siber uzay ve siber gözetimin tanımları yapılmış, ardından kurulan ilk sistemli gözetleme hapishanesi olan Panoptikon üzerinden günümüz siber gözetim sistemleri irdelenmiştir. Daha sonra çalışmada seçilen roman üzerinden gözetim ve birey incelenmiştir. Sonuç kısmında ise siber uzay içerisinde bireyin konumu eser üzerinden ulaşılan analizler ile yorumlanmıştır.

\section{Siber uzay ve siber gözetim}

Bilişim alanı geliştikçe yeni kavramlar ortaya çıkmakta ve farklı disiplinlere de etki etmektedir. Ancak siber uzay kavramı bilim kurgu romanından ortaya çıkarak bilişim alanında yer bulan bir kavramdır. Bu tanımı ilk olarak William Gibson, 1984 yılında yayınladığı Neuromancer isimli kitabında, genç, bir hırsız olan Case isimli sahsın bir jak ile siber uzay içerisinde bulunan sisteme bağlandığını ve işverenler tarafından verilen önemli yazılımlar sayesinde büyük şirketlerin sistemlerine giriş, yaptığını anlatarak yapmıştır (akt. Girgin, 2020: 38). Bu tanımlanan alan insanların veya devletlerin ağ üzerinden bağlanarak veri aktarımı yapabildiği bir yerdir. Nye'ye göre ise siber; "bilgisayar ve elektromanyetik spektrum ile ilgili faaliyetleri” ifade eden bir önektir (2011: 18). ABD Siber Uzay Politikası, siber uzayı hem Internet, telekomünikasyon ağları, bilgisayar sistemleri ve kritik endüstrilerdeki gömülü işlemci ve denetleyicileri içeren "birbirine bağlı bilgi teknolojisi altyapıları ă̆ı" hem de 'insanlar arasındaki sanal bilgi ve etkileşim ortamı" olarak tanımlar (House, 2009: 1). Schmitt ve Vihul ise; siber uzayı bilgisayar ağlarını kullanarak veri depolamak, değiştirmek ve değiştirmek için fiziksel ve fiziksel olmayan bileşenlerin oluşturduğu ortam olarak tanımlamaktadır (2017: 11). Kurulan bu ağ yeryüzünü ve uzayı kapsayacak şekilde geniş ve bu alanlarda güç dengesini değiştirecek kadar önemlidir. Birbiri ile ağ üzerinden bağlı bilgisayar sistemleri tarafından oluşturulmuş sanal bir gerçekliktir. Siber uzayı, birbirine bağlı bilgisayar ağları aracılığıyla erişilen sanal bir yer veya alan olarak tanımlayabiliriz. Aynı zamanda siber uzay zamansız, mekânsız ve anarşik bir yapıya sahiptir. Burada anarşiden kastedilen kaos ve düzensizlikten ziyade, belli bir merkez ya da merkezler tarafından yönetilemeyen, kontrol edilemeyen, idare edilemeyen çok kutuplu ya da çok merkezli sistemdir (Akyeşilmen, 2018: 59).

Siber uzay içerisinde insanlar özel bilgilerini, banka kayıtlarını, fotoğraflarını ve yaşamlarına ait görüntüleri sosyal medya aracılığı ile paylaşabilmektedir. Bu paylaşım kişiye özel olduğu gibi belirli bir gruba da yapılabilmektedir. Facebook, Twitter, Instagram gibi sosyal paylaşım ağları siber uzayın bize sağladığı mekân sayesinde ortaya çıkmıştır. Bireyler bu platformlar aracılığı ile gönüllü olarak kendilerini bir veri olarak bu alana kaydetmektedir. İnternet, tartışmasız mükemmel bir gözetim aracıdır (Bennett vd., 2012: 339). Sosyal medyada özel hayatımıza dair bilgilerin bulunması, başka kullanıcılar tarafından bu bilgilerin görülmesi ve izinsiz olarak alınabilip paylaşılması, bir diğer taraftan özel hayatın gizliliği ve siber gözetim endişelerini de beraberinde getirmiştir. Özellikle sosyal ağ siteleri ve ergen kullanıcılar bağlamında, kullanıcıların toplumda ve literatürde kişisel bilgilerin kullanımı konusundaki yetkinliği ve yeteneği yadsınamayacak düzeydedir (Fuchs, Boersma, Albrechtslund ve Sandoval, 2013: 255). Herhangi bir kullanıcı sosyal medyada kullandığınız fotoğrafınızı bilginiz dışında kopyalayabilir hatta sizin adınıza yeni bir web sayfası açabilir veya konum bilgilerinizi paylaştığınız sosyal medya siteleri sayesinde hırsızlar sizin evde olmadığınıza emin olarak evinizi soyabilir. Örneklerden de görüldüğü üzere sosyal medya ve internet hem özel hayatın gizliliği ilkesini ihlal etmek hem de siber gözetim sayesinde bireyleri mağdur etmek için kötü niyetli kişiler tarafindan kullanılabilmektedir.

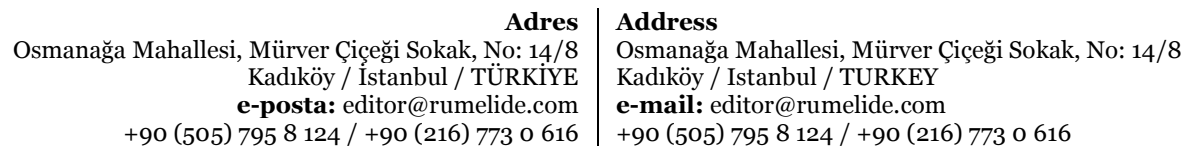




\section{Panoptikon'dan siber gözetime}

1791 ylında Jeremy Bentham'ın Panoptikon (Panopticon) isimli kitabında “gözetim” kavramı karşımıza çıkmaktadır. Londra'da basılan bu kitabın daha sonra Paris'te yayınlanmasıyla birlikte gözetim kavramı hızlı bir şekilde yayılmaya başlamıştır. Panoptikon, merkezi kulede yer alan hücrelerde mahkumların faaliyetlerini denetleyen bir gardiyan ile dairesel bir bina olarak tasarlanmış bir hapishaneyi tasvir etmektedir (Galič vd., 2017: 11). Binanın dairesel olması her bir hücrenin görülmesine olanak sağlamaktadır. Bu "her şeyi gören" mimari, merkezi bir "gözetleme" kulesine bakan bağımsız hücrelerle dolu halka şeklindeki bir binadan oluşmaktadır (Green, 1999: 29). Aydınlanma Çağı'nın değerlerini yansıtan Bentham'ın hapishane planı, suçluları kontrol etmek ve iyileştirmek için etkili ve verimli bir araç sağlayarak topluma fayda sağlayacağı düşünülmektedir (Campbell ve Carlson, 2002: 586). Belirli mimari tasarım sayesinde, sürekli gözetim yanılsaması yaratılır, aslında mahkumlar gerçekten sürekli olarak izlenmezler ancak sürekli gözetim altında olduklarına inanırlar. Gözetleme tek bir noktadan gerçekleştirilir ve bu genişletilmiş güce sahip olan, merkez locasındaki denetçidir. Gardiyan görünmezdir ve gardiyanın bu durumu "tamamen karanlık bir nokta" olarak algılanır (Boẓovič, 2010: 11). Gardiyan binanın mimarisi sayesinde her bir mahkûmu eş zamanlı olarak izleyebilir ve dolayısıyla gerçekte her şeyi gören gardiyandır. Bu panoptikondaki amaç, bireyin istenmeyen davranış olasılığını bulmak ve bu tür davranışları engellemek için izlemek, kategorize etmek ve sıralamaktır. Bir başka deyişle, Panoptikon, disiplinli ve "rasyonel" (öngörülebilir) vatandaşlar üreterek daha düzenli bir toplum sağlamak amacıyla sosyal kurumları organize etmenin bir yolu olarak görülmekteydi (Campbell ve Carlson, 2002: 587).

Foucault, 1975 yllında yayımladığı "Hapishanenin Doğuşu" (Discipline and Punish: the Birth of the Prison) isimli kitabında, İngiliz yazar Jeremy Bentham'ın çalışmalarından yola çıkarak, Panoptikon'u tekrar yorumlamıştır. Foucault, gözetim kavramını modern disiplin toplumlarının ortaya çıkışı bağlamında açıklamaktadır. Onun için Panoptikon aslında modern gözetim toplumlarının ideal bir yansıması olarak karşımıza çıkmaktadır. Panoptikon’u modern kurumlarda, özellikle hapishanelerde, işyerlerinde, kliniklerde, eğitim sistemlerinde ve iktidarların gözetim işlevini kavramsallaştırmak için kullanmıştır (Campbell ve Carlson, 2002: 589). Bu tür kurumlarda gözetim, iktidarın rahatlıkla hegemonyasını kurabileceği bir düzen yaratmaktadır. Gözetlenen ne zaman ve nasıl gözetlendiğini bilmediği için sürekli gözetleniyormuşçasına davranmaktadır. Bu gözetim aynı zamanda modern toplumlar için bir disiplin sembolüdür. Disiplini, insanları yönetmek, kontrol etmek ve normalleştirmek için operasyonel güç ilişkilerinin biçimleri ve tahakküm teknolojileri olarak anlar. Genel olarak bakıldığında bir disiplin toplumundan söz edilebilir ve bu disiplin toplumu süresiz olarak genelleştirilebilir ve bu yüzden disiplin toplumu bir tür sosyal karantinadır denilebilir (Foucault, 1995: 216).

Gözetim, "verileri toplanan kişileri etkilemek veya yönetmek amacıyla kişisel verilerin, tanımlanabilir olsun veya olmasın, her türlü toplanması ve işlenmesi” olarak tanımlanmaktadır (Lyon, 2001: 2). Foucault'nun gözetleme ve Panoptikon anlayışı, gözetim literatürünü inşa etmek ve gözetimin internet üzerinde nasıl ve ne amaçla yapıldı̆̆ını daha iyi anlamamızı sağlamaktadır. Görünüşte birbirinden farklı olan Panoptikon ve internetin yapı taşı aslında sadece gözetime dayanmaktadır. Panoptikon ve internet çeşitli kontrol amaçları için bireyleri ve popülasyonu değerlendirmek için metodik bir çaba içinde bilgi toplama ve gruplama teknolojilerini kullanır (Campbell ve Carlson, 2002: 587).

Siber uzay denetlenmesi ve kontrol edilmesi zor olan bir alandır ve bu alan üçüncü kişilerin dikkatini çekecek verilerle doludur. Siber gözetim çok çeşitli aktörler tarafından yürütülmektedir. Ordu,

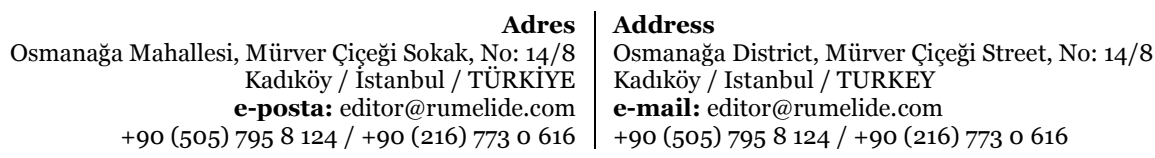


hükümet, komşunuz ve iş arkadaşınız herhangi bir nedenle, belirli veya hatta spesifik olmayan nedenlerle başka veri veya istihbarat toplamak isteyebilir (Shimonski, 2014: 17). Bireysel olduğu kadar devletler boyutunda da güç uygulanabilecek bir alana dönüşmüştür. Sadece ticari sırlar değil, güvenliği etkileyecek veriler de bu alanda yer aldığı için elde edilen veriler oldukça değer kazanmaktadır. Siber uzayın gayri merkezi, sınırları olmayan, ağ biçimindeki yapısı onun herhangi bir devletin, dolayısıyla herhangi bir hukuk düzeninin yek egemenliği altına sokulmasına engel olmakta ve vatandaşlık, ulusal sınır gibi kavramların çok da anlam taşımadığı bu ortamda, ülkelerin egemenlik yetkilerini meşrulaştırmasına, başka bir deyişle hukuk kuralı koyma ve uygulama haklarını sağlam temeller üzerine oturtulmasına ihtiyaç, duyulmaktadır (Yayla, 2013: 181). Ülkeler bu boşluklardan dolayı ciddi zararlara uğrayabilmektedir. Robinson (2012), ABD istihbarat yetkililerinin 2009 yllında ABD firmalarının yaklaşık 50 milyar dolar değerinde fikrî mülkiyet hırsızlığına maruz kaldığını iddia ettiğini söylemektedir (akt. Hekim ve Başı̈üyük, 2013: 153).

Yönetimler sadece karşılıklı casusluk yapmak için bu aracı kullanmamaktadırlar. Böylesine büyük bir yapı beraberinde erkin gücünü toplum üzerinde gösterebilmesi için uygun bir zemin hazırlamıştır. Bireylerin hareketlerinin kontrol edilmesi ve yönlendirilmesi insanların yazıyı bulması kadar eskidir. Basılı yayınlar ile birlikte devletin gözetim faaliyetleri hız kazanmıştır. Kurumlar üzerindeki etkisi artış gösterirken, sistemli bir gözetleme modernizm ile birlikte başlamıştır.

21.yüzyll neredeyse her bir bireyin her anının gözetlenebildiği bir dönemdir. Toplum sürekli kayıt alan kablolu ya da kablosuz bilgisayar ağları ile sarmalanmıştır. Siber uzayda özellikle özel şirketler veri toplama, depolama ve veriyi kategorize etme bağlamında devletlerden üstün konumda bulunmaktadırlar. Dolayısıyla devlet gözetim yaparken kendi araçlarını kullanabildiği gibi özel şirketler aracılı̆̆ıyla da bireyleri gözetime tabii tutabilir. Dolayısıyla modern toplumda bir yerden başka bir yere gözetim olmaksızın gitmek neredeyse imkansızdır. Elektronik devlet (e-devlet), gözetim odaklı toplumda temel bir role sahiptir. Örneğin Havaalanları, gözetim toplumunun somut bir ürünü olarak karşımıza çıkmaktadır. Havaalanı güvenliği, yolcuların anonimliğini reddetmek için teknolojiyi kullanır. Bekleme salonlarında ve kontrol noktalarında, yolcuların kimliği havaalanı girişinden ve güvenlik kontrollerinden geçerken dahi bilinebilmektedir. Dolayısıyla havaalanları, ulusal sınırların ötesinde özel sektörle el ele, iktidar tarafından gözetim için son derece entegre bir alandır (Ogura, 2006: 281-283). Yine toplum içerisinde her yerde bulunan kapalı devre kameralarıyla sokak gözetleme otomasyonuna maruz bırakılmaktayız. Ancak bir suç mağduruysak ya da suça karışmışsak bu kayıt altına alınan görüntüler süreci değiştirebilmektedir (Graham, 2005: 572). Bu da gözetimin aslında sadece siber uzayda değil günlük hayatımızın da bir parçası olarak karşımıza çıktığını bizlere göstermektedir.

\section{Kafka ve Dava}

Çalışmanın çıkış noktası insanların, erk tarafından kontrol edilmek için sürekli izlenmesi ve gözetim altında tutmasıdır. Teknolojik gelişmelerle birlikte bu gözetim siber uzayda bilgisayar ağları üzerinden gerçekleşebilmektedir. Bu durumun önceden tahlilini yapan ve arada kalan bireyin ruh halini en iyi yansıtanlardan biri de Franz Kafka olmuştur. 1883-1924 yılları arasında yaşamış olan Kafka içinde bulunduğu dönemde, şehir hayatında yeni bir düzene ayak uydurmaya çalışan, var olma mücadelesi veren ve bu mücadele sırasında kendi değerlerini sorgulayan bireyi eserlerinde yansıtmıştır. Dönüşüm (1915) eserinde bir sabah böcek olarak uyanan Gregor Samsa ve Dava (1925) eserinde yine bir sabah tutuklanan Joseph K. yansitılan çaresiz birey konusunda iyi örneklerdir. Özelikle Joseph K. toplum ve erk tarafından gözetim altında tutulan, her hareketi başkaları tarafından izlenen bir karakterdir.

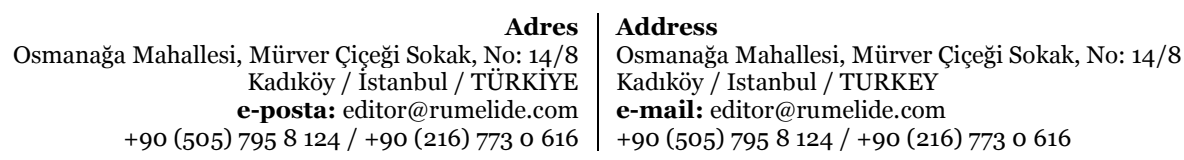


Yaşadığı korku onun önce paniklemesine ardından ise durumu kanıksamasına yol açmıştır. Karakterin çaresizliği kitap çevirisinin kapağında; dava, Korku Çağı diye adlandırılan yirminci yüzyılda insanoğlunun artık neredeyse kurtulması imkânsız bir yazgıya dönüşmüş olan kuşatılmış yaşamın öyküsüdür denilmektedir şeklinde vurgulanmıştır (Kafka, 1999). Kafka’nın eserleri sıklıkla modern dönemin sıkıntılarının dışavurumu olarak yorumlanır ve kullandığı semboller hem insanın üzerinde baskı kuran bürokrasi sürecini hem de aile içerisinde yaşadığı baba korkusunu betimler (Reinhard, 2013: 44). Dava romanında ana karakterin bir üst otoriteye erişememesi ve bürokratik süreçlerden haberdar olamaması sonucunda kaygılı ve öfkeli olduğu görülmektedir. Bunun nedeni ise siber uzayda bir üst otoritenin olmaması bir başka deyişle siber uzayın anarşik bir yapı olmasıdır. Dolayısıyla kendisi hakkında her tür bilgiye gözetim yoluyla sahip olan erk ve bu elde edilen bilgilerle ilgili hiçbir kontrolü olmayan bir karakter karşımıza çıkmaktadır.

Dava, bir sabah aniden tutuklanan ve buna rağmen işine gidip hayatına devam etmesine izin verilen bir adamın öyküsüdür. Dava sürecinde ana karakter ne mahkemeye çıkartılır ne de savcı ile görüşür. Görünmez mahkemenin alt kademesindeki temsilcileri dışında süreç hakkında ona bilgi veren kimse yoktur. Suçunu öğrenebilmek için çaba gösterse de bunu başaramamıştır. Çalıştığ 1 bankadaki iş arkadaşları, komşuları ve onu tanıyanlar bir şekilde bu davadan haberdardır. Herkesin onu izlediğini anlayan Joseph K. bu görünmez mahkeme ile mücadele edemeyeceğini anlar ve tek suçlunun kendisi olduğuna kanaat getirir. Sonunda işlediği suçu bilmese bile suçun varlığını kabullenerek kendisini almaya gelen infaz görevlilerine direnmez ve onlarla birlikte ölümünün gerçekleşeceği taş ocağına doğru gider. Ölmeden önce ona uzaktan bakan ve elini uzatan birini görür ama artık bir önemi kalmamıştır. Çünkü hiçbir zaman öğrenemediği suçunu içselleştirmiş ve kaderine boyun eğmiştir.

Gözetim, Dava eserinin temel konusudur ve ana karakter Joseph K. bu gözetimin getirdiği tutuklamadan dolayı kendisinin suçsuz olduğunu çaresizce kanıtlamaya çalışan bir bireydir. Bir sabah odasına aniden giren insanlar kendisine tutuklandığını bildirirler. Bu duruma önce şaşırsa da ardından ne yapmış olabileceğini sorgular. Bu sorgulama okuyucuya bireyin kendisini gönüllü olarak soktuğu kafeste aslında gözetim altında olduğunun farkındalığını gösterir. "Bunları yüksek sesle söylememesi gerektiğini, çünkü böyle yapmakla yabancının onu gözetim altında tutma hakkını bir ölçüde tanıdığını gerçi hemen anlamıştı, ama bu nokta onca şimdilik önemli değildi” (1999: 18) cümlesi okuyucuya gösterilen bu farkında olma durumunun bir yansımasıdır. İçinde bulunduğu toplumu sorgularken de "Nasıl insanlardı bunlar? Neden söz ediyorlardı? Hangi resmi makamdandılar? K., bir hukuk devletinde yaşıyordu, her yerde barış ve huzur vardı, tüm yasalar yürürlükteydi, kimdi bu durumda evini basma cüreti gösterenler?” (1999: 20) şeklinde ifade ediyordu. Evine gelenleri tanımlarken gözetmen ifadesi kullanması ve karşı pencereden onu izleyenlerin bulunması ağlar üzerinden her hareketimizin izlendiği ve üçüncü kişilere bilgilerimizin hızla aktarılabildiği siber gözetimin bir örneği olarak karşımıza çıkmaktadır: "Karşıdakiler hala yerlerindeydiler, ama şimdi K.'nın da pencereye gelmiş olmasından ötürü eskisi kadar rahat bakamıyorlardı...K. iyice yüksek sesle: Orada da böyle izleyiciler var, diye bağırdı gözetmene ve işaret parmağıyla dışarısını gösterdi”(1999: 29).

Gündelik hayatta izlenmenin, takip edilmenin sıradan bir hal alması, Panoptikon içindeki mahkumların orada gözetleyen olmasa bile gözetlendiklerini düşünmeleri gibi bu durumun sıradanlaşması eserde şu şekilde karşımıza çımmaktadır;

“Tutuklandınız hiç kuşkusuz, ama bu, uğraşınızı engellemeyecek. Normal yaşamınızı sürdürmekten de alıkonmayacaksınız. O zaman tutuklanmış olmak pek kötü değil dedi K.” (1999: 31).

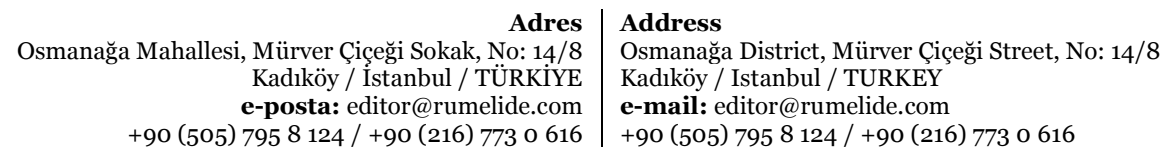


Bay K. bu durumu içselleştirmiş ve dahası işe gidebilmesi ve gündelik hayatına devam edebilmesini olayın iyi tarafı olarak görmüştür.

Romanda soruşturma odası sıradan bir evin odasında kurulmuş olarak tasvir edilir. Joseph K.'nın tesadüfen girdiği bir binanın içinde yine tesadüfen bulduğu bir oda içinde seyircilerin olduğu bir mahkemedir. "Sonunda yine de ilk merdivenden yukarı çıtı ve bunu yaparken, nöbetçi Willem'in, suçun mahkemeyi kendine çektiği yolundaki sözü hatırladı... soruşturma odasının K.'nın rastgele seçtiği merdivende bulunması gerekiyordu" (1999: 52). Siber gözetimin sinılarının olmaması, karşımıza her an her yerde çıkabilmesi yani mekânsız olması Kafka'nın eserindeki bu gönderme ile örtüşmektedir.

Joseph K. kendi davası için farklı insanlarla görüşmeye başlar ve her bir kişi, amca, papaz, ressam, fabrikatör kendisine yol gösterse de Kafka'nın karaktere yaptırdığı bu yolculuk sonunda K.'nın iç sesleri ile son bulur. Dava süresi belirsizdir ve bu belirsizlik sürekli gözetimin bir göstergesidir. "Bu yolla aklandığınız takdirde şimdilik davadan uzaklaşmış olursunuz, fakat dava ondan sonra da başınızın üzerinde sallanmaya devam eder ve daha yüksek emir gelir gelmez hemen yürürlüğe girer” (1999: 168). Mekânsız, zamansız bir dava 20. yüzylla gözetim altında olan insanların sürekli kendilerini kontrol etme zorunluluğu hissetmelerine yol açabilmektedir. 21. yüzylda ise bu gözetim devam etmektedir ancak sadece gözetimde kullanılan araçlar değişmiş olarak karşımıza çıkar.

Joseph K. artık kendisini tamamen sisteme teslim etmiş ve sonuçlarına da hazırlamıştır. Dava'nın sonucunda ölüm kararı uygulanırken hiçbir itirazda bulunmaz ve sakince sonunu bekler. "Onların tüm çabalarına ve K.'nın onlara gösterdiği bütün kolaylığa rağmen inandırıcı olmaktan uzak bir konumdaydı, (...) hiçbir zaman görmediği yargıç neredeydi? Asla ulaşamadığı yüksek mahkeme neredeydi? (...) utanç ondan sonra da hayatta kalacaktı" (1999: 240) ifadesiyle bireyin kendisini kuşatan gerçek ya da sanal ağlardan kurtaramadığı için umutsuzca ama içinde kalan son değer imgesi olan utançla varoluşunu sürdürmek durumunda kaldığı vurgulanmaktadır. Kafka'nın burada hayatına son verdiği karakter iktidara direnmenin çaresizliği içerisinde bilmediği suçunu kabul etmiş ve erke teslimiyetin önemli bir sembolü olmuştur.

\section{Sonuç}

İnsanlar teknoloji sayesinde daha mutlu, daha sağlıklı, daha güzel olmayı, teknolojinin kendilerini bedenen ve ruhen refaha kavuşturmasını bekler. Aynı zamanda da erkten, özgürce ve güven içerisinde yaşayabileceği alanlar oluşturmasını ve bunu sürekli kılmasını ister. Bunları talep ederken sosyal yaşam içerisinde kendi varlığından bazı ödünler vermesi gerekmektedir. Çünkü toplum birbirini etkileyen, gözlemleyen ve gözlemlenen çok sayıda bireyin bir arada yaşamasıdır (Thomas, 1992: 10). Toplum içindeki bireylerin oluşturduğu erk, bu talep edilen istekleri karşlarken aynı zamanda yönettiği bireyleri şekillendirmeye başlar. Teknolojik gelişmeler de toplumun inşa sürecinde faydalı araçlara dönüşür. Birey toplum içerisinde kendisinden beklenen bir davranışı, sahip olduğu benlik ile karşılayamazsa, bu beklentiyi kendisine zorla verilmiş toplumsal rol ile karşılar (Schimank, 2013: 20). $\mathrm{Bu}$ roller ise erkin sahip olduğu medya ve diğer kitle iletişim araçları sayesinde topluma empoze edilir. Siber uzay içerisinde bilgisayar ağları üzerinden bireyler, diğer bireylerle, şirketlerle ve devletlerle bağlı konuma gelmiştir. İnternette tüm bilgilerimizin sanal ağlar üzerinden ulaşılabilir olması yaşamı kolaylaştırsa da üçüncü kişilerin bunu ele geçirebilme ihtimali beraberinde korkuyu getirmektedir.

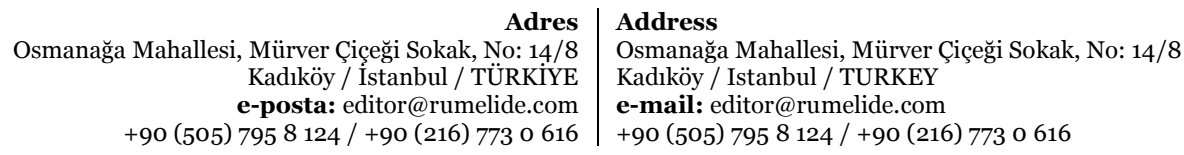


Korku insanları hızlı düşünmeye ve ani kararlar vermeye sevk eder. İnsanlar doğaları gereği, tehlikeli olarak değerlendirdikleri durumlardan mümkün olduğu kadar uzak kalmak, eğer bu durumun içindelerse de kaçmak, kendilerini korumak isterler ve bundan dolayı korku, içerdiği tehlike düşüncesi neticesinde, beraberinde korunma, kaçma davranışı getiren bir duygudur (Gençöz, 1998: 10). Bu nedenle insanlar korkularının çözümü olarak erkin belirli konularda özgürlüklerini kısıtlamasına rıza gösterirler. Etrafımızı saran gözetim kameraları bunun en iyi örneğidir. Olası tehlikeli durumlar için bizleri koruyan aygıtlar olarak düşünülse de dönüştüğü şey gözetim kuleleridir. Trafikte yol kenarında gördüğümüz bir kamera, ne için orada olduğundan bağımsız olarak bizim yasal sınırlar içerisinde hareket etmemize rağmen daha yavaş gitmemize sebebiyet verebilmektedir. Çünkü birey, bu gözetim mekanizması karşısında tıpkı Joseph K. gibi "bilmediğim bir kuralı ihlal ediyor olabilirim" diye düşünmektedir. Sürekli gözetim altında tutulan birey kendi hayatını şekillendirirken sadece toplumsal normlarla değil aynı zamanda üretilmiş normlarla da karşı karşıya kalır. Bu durum insanın birey olma, kendisini var etme yolunda zarar görmesine yol açar.

Dava, Kafka öldükten sonra 1925 yllında basılmıştır ve yazar günümüzden yüzyıl öncesinde bireyin içinde bulunduğu durumu analiz etmiş ve git gide sıkışan, gözetim altına alınan insanın sonunda mutlu olamayacağını öngörmüştür. Ardından Foucault'un, Bentham'ın Panoptikon tasarımı üzerinden gözetim kavramını yeniden ele alması ile bu konu günümüzde siber gözetime kadar gelmiş ve güncelliğini korumuş, literatürde yerini almıştır. Sağlıklı toplumların inşa edilebilmesi için bireyin güçlü ve özgür olması gerekmektedir. Bireylerin Joseph K. gibi bir sona gitmemesi için toplumsal normları sorgusuz içselleştirmek yerine sorgulaması ve yapay normlara karşı bilinçli yaklaşması gerekmektedir.

\section{Kaynakça}

Akyeşilmen, N. (2018). Disiplinlerarası Bir Yaklaşımla Siber Politika \& Siber Güvenlik. Ankara: Orion Kitabevi.

Bennett, C. J., Clement, A., Milberry, K. (2012). Introduction to Cyber- Surveillance. Surveillance \& Society, 9(4), 339-347.

Božovič, M. (2010). Introduction: 'An utterly dark spot. In M. Božovič (Ed.), The panopticon writings (pp. 1-28). London: Verso Books.

Campbell, J. E.; Carlson, M. (2002). Panopticon.com: Online surveillance and the commodification of privacy. Journal of Broadcasting \& Electronic Media, 46(4), 586-606.

Çiçek, N. (2015). Franz Kafka'nın eserlerinde yabancılaşma problemi, Beytulhikme An International Journal of Philosophy, 141-162. Doi: 10.18491/bijop.97020.

Foucault, M. (1995). Discipline and Punish: the Birth of the Prison. 1975. New York: Vintage, 1, 977.

Fuchs, C. (2017). Social media: A critical introduction. Sage.London.

Fuchs, C., Boersma, K., Albrechtslund, A., Sandoval, M. (Eds.). (2013). Internet and surveillance: The challenges of Web 2.0 and social media (Vol. 16). Routledge.

Gençöz, T. (1998). Korku: Sebepleri, Sonuçları ve Başetme Yolları. Kriz Dergisi 6 (2): 9-16.

Girgin, O. (2020). Siber Uzay'da Üstünlük Mücadelesi; Amerika Birleşik Devletleri ve Rusya Federasyonu. Academic Review of Humanities and Social Sciences, 3(1), 36-58.

Graham, S. D. (2005). Software-sorted geographies. Progress in human geography, 29(5), 562-580.

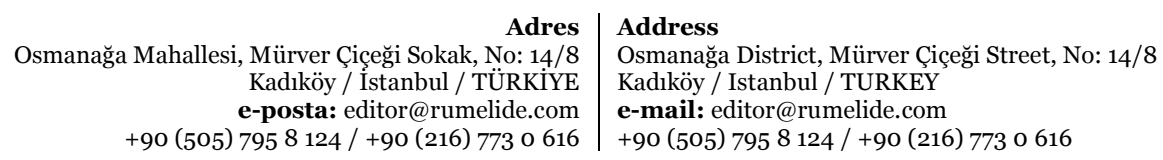


Green, S. (1999). A plague on the panopticon: Surveillance and power in the global information economy. Information, Communication \& Society, 2(1), 26-44.

Hekim, H.; Başıüyük, O. (2013). Siber Suçlar ve Türkiye'nin Siber Güvenlik Politikaları. Uluslararası Güvenlik ve Terörizm Dergisi, 4(2), 135-158.

House, W. (2009). Cyberspace policy review. Assuring a Trusted and Resilient Information and Communications Infrastructure." Washington, DC: White House.

Joseph S. (2011). Nye, 'Nuclear Lessons from Cyber Security?', Strategic Studies Quarterly, 18.

Kafka F. (1915). Der Prozess. Çev. Cemal A. İstanbul, Can Yayınları, 1999.

Lyon, D. (2001) Surveillance Society: Monitoring Everyday Life (Milton Keyes: Open University Press).

Ogura, T. (2006). Electronic government and surveillance-oriented society. Theorizing surveillance: The panopticon and beyond, 270-295.

Reinhard, N., (2013). Machtdispositiv Und Gender In Kafkas Romanfragment Der Verschollene. By: Meridian Critic, 20696787, Vol. 20, Issue 1.

Schimank, U. (2013). Das zwiespältige Individuum: Zum Person-Gesellschaft-Arrangement der Moderne. Springer-Verlag.

Shimonski, R. (2014). Cyber reconnaissance, surveillance and defense. Syngress.

Thomas, A. (1992). Grundriß der Sozialpsychologie: Individuum-Gruppe-Gesellschaft (Vol. 2). Hogrefe Verlag.

Yayla, M. (2013). Hukuki Bir Terim Olarak Siber Savaş. Türkiye Barolar Birliği Dergisi, 104, 177-202. 